\title{
Firm performance: the moderation impact of debt and dividend policies on overinvestment
}

\author{
Nghia Nguyen Trong \\ School of Banking and Finance, \\ University of Economics and Law, Vietnam National University Ho Chi Minh City \\ (VNU-HCM), Ho Chi Minh City, Vietnam, and \\ Cong Thanh Nguyen \\ Department of Economics and Finance, \\ RMIT International University - Saigon South Campus, Ho Chi Minh City, Vietnam \\ and \\ School of Finance - Commerce, Ho Chi Minh City University of Technology, \\ Ho Chi Minh City, Vietnam
}

\begin{abstract}
Purpose - Debt, dividend and investment policy constitutes a company's important financial decisions to determine firm performance. The research emphasizes on the problem of overinvestment, a phenomenon that worsens firm operation. Furthermore, it clarifies the moderation role of debt and dividend policy in mitigating the negative effect of overinvestment on firm performance in the case of Vietnamese listed companies.

Design/methodology/approach - The research uses all financial statement of non-financial Vietnamese listed companies on Ho Chi Minh and Hanoi Stock Exchange in the period of 2008-2018. The data are collected from Thomson Reuters Eikon. The final data set is comprised of 669 listed companies. The study measures overinvestment though investment demand function and HP filter. Moreover, the research employs the dynamic model, so it has to apply the SGMM method to deal with the problem of endogeneity caused by the lagged dependent variable.

Findings - The research finds that overinvestment is negatively associated with firm performance. Debt or dividend policy separately can moderate the negative effect of overinvestment on firm performance. However, when these two policies are combined, they lessen the positive interaction impact of each policy due to the substitution between debt and dividend policy.

Research limitations/implications - The research may have two limitations. Firstly, the research measures overinvestment indirectly through investment demand function and HP filter. These two measures only help identify the sign that companies may have the problem of overinvestment because we cannot determine whether they overinvest or not in reality. Secondly, when using interaction variables, the problem of multicollinearity may be higher, and this may adjust the signs and significance level of variables in the models. Practical implications - Practically, the research proposes three policy recommendations. Firstly, a company can exploit debt or dividend policy to limit excessive free cash flow in order to constrain the problem of overinvestment. Secondly, a company should enhance its corporate governance to resolve agency problems. Thirdly, the government should make the financial sector more transparent and effective to improve monitoring functions of various parties in the capital market.

Social implications - Overinvestment sometimes can cause social issues. Overinvestment means that companies make ineffective investment. If they continue this situation over a long time, companies may have
\end{abstract}

\section{JEL Classification - M31, G35.}

(C) Nghia Nguyen Trong and Cong Thanh Nguyen. Published in Journal of Asian Business and Economic Studies. Published by Emerald Publishing Limited. This article is published under the Creative Commons Attribution (CC BY 4.0) licence. Anyone may reproduce, distribute, translate and create derivative works of this article (for both commercial and non-commercial purposes), subject to full attribution to the original publication and authors. The full terms of this licence may be seen at http:// creativecommons.org/licences/by/4.0/legalcode

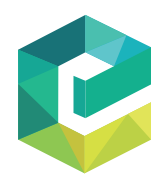

Received 5 January 2020

Revised 16 February 2020 25 March 2020

Accepted 26 March 2020 dividend policy on overinvestment 
JABES 28,1

financial distress or even go bankruptcy. As a result, it will slow down economic growth and increase unemployment in the economy.

Originality/value - The research is supposed to make two great contributions to the existing empirical studies in two aspects. Firstly, it is the first attempt to take into consideration the interaction between overinvestment and financial policies. Secondly, it helps enhance the fundamental stance of the agency theory, which supports the interdependence of debt, dividend and investment policy.

Keywords Overinvestment, Debt policy, Dividend policy, Firm performance, Vietnamese listed companies Paper type Research paper

\section{Introduction}

Financial policies including debt, dividend and investment policy constitute an important triad within corporate enterprises (Alli et al., 1993; Baker and Powell, 2000). Debt policy refers to how much debt to leverage, dividend policy means how much dividends to pay and investment policy relates to how much investment to make (Hao et al., 2018; Al-Najjar and Kilincarslan, 2019). Therefore, these three financial policies are interdependent and collectively determine firm profitability. However, over the past decades, the collective role of these policies has received so many debates among the academic community around the world. Discussions started with Modigliani and Miller (1958), who demonstrated the irrelevance of debt and dividend policy to investment policy as well as firm performance in a perfect capital market without taxes, costs of all kinds and information asymmetry. On the other hand, in an imperfect capital market, these assumptions are strongly criticized, suggesting the interdependence among these three financial policies in a company's decisionmaking process towards improving profitability.

A company's profitability is partly dependent on investment strategies in the context overwhelming with uncertainties (Kannadhasan and Aramvalarthan, 2011). During the management process, managers have to efficiently allocate capital resources to achieve optimal investment level at which the marginal profits are equal to the marginal costs. Any investment that exceeds the optimal level signals inefficient investment decisions. Thus, the problem of overinvestment, the excessive investment compared to expected investment need, makes a company's operation less effective. Motivations towards overinvestment originate from the misalignment of interests between managers and investors (Shi and Gao, 2018). Managers attempt to enlarge assets under their management to accumulate personal benefits, while investors pay attention to profit maximization to raise firm value in the future (Badavar Nahandi and Taghizadeh Khanqah, 2018; Li et al., 2019). As a result, managers expand investment level, increasing the probability of investing in projects with negative net present value (NPV) (Ding et al., 2019; Bhuiyan and Hooks, 2019). To constrain such a discretionary behaviour, investors incur great costs of monitoring their representatives to align the interests between the two sides. Both ineffective investment decisions and expensive monitoring costs deteriorate firm performance (Jensen, 1986; Shima, 2010; Grazzi et al., 2016; Gu, 2013).

Based on the viewpoint of agency theory, the use of debt and payment of dividends require managers to make efficient investment to increase profitability and fulfil their commitments to not only debtholders but also shareholders (López-de-Foronda et al., 2019; Wei et al., 2019; Ali et al., 2019). Hence, the utilization of investment policy together with debt and dividend policy shares the monitoring burden with various parties in the capital market, reducing a company's monitoring costs (Easterbrook, 1984; Lei and Chen, 2019; Kim, 2018; Jiang et al., 2019). Therefore, the problem of overinvestment is attenuated when a company makes a specific plan on debt, dividends and investment together and adjusts one of the three instantly to maintain profitability and maintain firm performance (DeAngelo et al., 2006). Existing literature review only emphasized on the determinants of these financial policies or their impacts on firm performance (Alsharairi et al., 2018; Kumar and Ranjani, 2018). 
However, their inter-moderating effect towards each other and collaborative impact on profitability have not been examined. The research aims to identify the impact of overinvestment (investment policy) on profitability and clarify the role of debt and dividend policy on the relationship between overinvestment and performance. Two main research questions are put: (1) Does overinvestment negatively affect firm performance? (2) How do the other two policies moderate such a negative effect?

Vietnamese listed companies are chosen as a sample in the research due to two major reasons. Firstly, Vietnam's financial market is underdeveloped with weak institutional quality and severe information asymmetry, and commercial banks provide the large majority of financing sources to enterprises. Secondly, the problem of overinvestment is neglected in this country though the conflicts of interests between shareholders and managers are serious in Vietnamese companies. The research data is collected from Thomson Reuters Eikon for all financial statements of Vietnamese listed companies in the period of 2008-2018. Furthermore, overinvestment is measured in two ways by using HP filter and investment demand function (the positive residuals from the sub-equation). These two new measures are considered to be more appropriate proxies for overinvestment than Tobin's $\mathrm{Q}$ because they are based on various determinants of investment policy as well as data on the amount of investment.

From the estimated results, overinvestment is more likely to worsen profitability. Nevertheless, when taking into account either debt policy or dividend policy together with investment policy, the negative effect of overinvestment on profitability can be lessened. Surprisingly, when these three policies are combined in the decision-making process, debt and dividend policy can hamper the positive influence of the two-variable interactions. The coefficient signs of variables imply that debt policy and dividend policy can substitute each other through the negative sign of the single debt and dividend policy and the positive sign of their interaction. Applying two different representatives for overinvestment is also a way to check the model robustness. All signs and significance level in various models with the alternative combination of two overinvestment measures and six profitability proxies are consistent, indicating the strong validity of the regression model. In short, the results are supposed to make two contributions to the existing empirical review in two respects. First, the study is the first attempt to consider the interaction among three financial policies and their impacts on firm performance. Secondly, our results support the agency theory, which suggests the interdependence among debt, dividend and investment policy. In addition, these findings and contributions can give shareholders certain recommendations in resolving agency problem within corporate enterprises.

The research is structured into five sections. Section 2 reviews theoretical and empirical studies to help develop research hypotheses. Section 3 describes data collection, clarifies overinvestment measurement and establishes model specification. Section 4 presents estimated results and discussions. The final section summarizes the whole research and provides some policy recommendations for both mangers and shareholders.

\section{Literature review and hypothesis development}

A perfect capital market proposes some assumptions including (1) no taxes, transaction and bankruptcy costs among market participants; (2) two-way information symmetry between shareholders and managers; (3) fair debt burdens between shareholders and debtholders (Modigliani and Miller, 1958; Miller and Modigliani, 1961). Relaxing any assumption paves the way for the development of other theories on the imperfect capital market. Trade-off theory expresses the benefit of debt tax shield and the cost of financial distress (Modigliani and Miller, 1963); tax theory illustrates dividend pay-outs under different tax brackets (Litzenberger and Ramaswamy, 1979); pecking order theory emphasizes on the financing hierarchy from least to most liquid sources (Myers and Majluf, 1984); bird-in-hand theory supports the role of 
JABES

28,1

50

dividends in reducing uncertainties (Gordon, 1959, 1963); agency theory indicates the conflicts of interests between managers and shareholders (Jensen and Meckling, 1976).

Conflicts of interests occur due to divergence in ownership rights of shareholders and management rights of managers (Jensen and Meckling, 1976). Having a comprehensive understanding of internal operation, managers make decision to benefit themselves with higher salary, promotion and property under their control. Such an underlying motivation explains for overinvestment. In case shareholders fail to detect their behaviours through monitoring business activities, the problem may deteriorate (Myers and Majluf, 1984; Brealey et al., 2008). Consequently, overinvestment will result in investment in projects with negative NPV and indirectly destruct firm value (Liu and Bredin, 2010; Titman et al., 2004; Yang, 2005; Fu, 2010; Ding et al., 2019; Badavar Nahandi and Taghizadeh Khanqah, 2018).

Various empirical research studies have demonstrated the negative association between overinvestment and profitability. Shima (2010) finds the negative effect of overinvestment in the sample data for listed Singaporean companies in the period of 2005-2011; Faroog et al. (2014) categorize investment into three different levels including overinvestment, optimal investment and underinvestment for Chinese listed companies from 1998 to 2014. They clarify that only optimal investment is effective in corporate enterprises in this country; Guariglia and Yang (2016) suggest that rarely does investment reach the optimal level due to agency problems which limit financing access as well as worsen firm performance; finally, Liu and Bredin (2010) and Yang (2005) also prove that overinvestment is negatively related to firm performance. Ultimately, the research develops the first hypothesis on the overinvestment-performance relationship.

H1. Overinvestment adversely affects firm performance.

Excessive free cash flow creates an opportunity for managers to benefit themselves by using the discretionary funds to increase resources under the control and enhance their position through making more investment (Shi and Gao, 2018; Yeo, 2018; Shi, 2019; Hao et al., 2018). Therefore, reduction in free cash flow is a solution to the expropriating behaviours of managers (Jensen, 1986; Ali et al., 2019). In this situation, both debt and dividend policy can help restrain the bad effect of overinvestment with lower free cash flow in corporate enterprises and better monitoring tasks from outside parties (Rozeff, 1982; Easterbrook, 1984; Jensen, 1986; Alli et al., 1993; Biddle et al., 2009; Al-Najjar and Kilincarslan, 2019; Cho et al., 2019). Similarly, Richardson (2006) emphasizes on the monitoring role in limiting excess free cash flow. Furthermore, Lang and Litzenberger (1989) demonstrate that a decrease in overinvestment can heighten firm value and raise dividend payment. Grossman and Hart (1982) hold that a company's utilization of debt may result in financial distress or even worse bankruptcy, but at the same time, strict debt covenants from debt creditors. If a company continues to put more investment in bad projects, managers may place themselves at risk of losing perquisites. In short, the second hypothesis for the moderation effect of debt and dividend policy is proposed.

H2. Debt or dividend policy may moderate the negative relationship between overinvestment and firm performance.

\section{Data methodology}

\subsection{Data collection}

The research collects financial statements of Vietnamese listed companies from Thomson Reuters Eikon. All companies are listed in Hanoi Stock Exchange (HNX) and Ho Chi Minh Stock Exchange (HOSE) from 2008 to 2018. Based on the random selection, companies with less than five consecutive years of operations are excluded from the data sample. Moreover, only non-financial companies are taken into consideration because financial ones including 
commercial banks, insurance agencies and financial institutions have different characteristics from other kinds of companies with regard to accounting and managing practices. The final sample is composed of 669 non-financial listed companies covering 49 various industries in Vietnam's economy. However, due to the problem of delisting, some companies have lack of observations. Therefore, the research uses the unbalanced panel data for the regression model.

\subsection{Model specification}

Because current performance depends on past performance, following Chen et al. (2017) and Altaf and Shah (2017), the study applies the dynamic model with the one-period lag of firm performance. Besides, the regression examines main independent variables including overinvestment and the moderation effects of debt and dividend policy. The regression specification is as follows:

$$
\begin{aligned}
\text { Performance }_{i, t}= & \lambda_{0}+\lambda_{1} \text { Performance }_{i, t-1}+\lambda_{2} \text { Size }_{i, t}+\lambda_{3} \text { Growth }_{i, t}+\lambda_{4} \text { Risk }_{i, t} \\
& +\lambda_{5} \text { Liquidity }_{i, t}+\lambda_{6} \text { Tangibility }_{i, t}+\lambda_{7} \text { Dividend }_{i, t}+\lambda_{8} \text { Debt }_{i, t} \\
& +\lambda_{9} \text { Overinvestment }_{i, t}+\lambda_{10} \text { Dividend }_{i, t} \times \text { Debt }_{i, t} \\
& +\lambda_{11} \text { Debt }_{i, t} \times \text { Overinvestment }_{i, t}+\lambda_{12} \text { Dividend }_{i, t} \times \text { Overinvestment }_{i, t} \\
& +\lambda_{13} \text { Dividend }_{i, t} \times \text { Debt }_{i, t} \times \text { Overinvestment }_{i, t}+\mu_{i, t}
\end{aligned}
$$

where Performance ${ }_{i, t}$ and Performance ${ }_{i, t-1}$ are respectively performance and one-period lag of performance proxied by earnings before interests and taxes (EBIT), earnings before taxes (EBT) and earnings after taxes (EAT) over total assets; Dividend ${ }_{i, t}$ is dividend payment; Debt $_{i, t}$ is total debt over total assets; Overinvestment $t_{i, t}$ is the positive residuals taken from investment demand function in Table A2 or the fluctuation from the trend line obtained from HP filter technique; Size $i_{i, t}$ is the natural logarithm of total assets; Growth ${ }_{i, t}$ is sales growth; Risk $_{i, t}$ is profitability variation; Liquidity ${ }_{i, t}$ is quick ratio; Tangibility ${ }_{i, t}$ is fixed assets over total assets [1].

In the research, apart from the single effect of each variable, the research also considers the marginal effects based on interaction variables in the regression model. The marginal effects of leverage, dividend and overinvestment are explained through partial derivatives of firm performance with respect to each respectively.

\subsection{The marginal effect of debt}

$$
\begin{aligned}
\frac{\partial \text { Performance }_{i, t}}{\partial \text { Debt }_{i, t}}= & \lambda_{8}+\lambda_{10} \text { Dividend }_{i, t}+\lambda_{11} \text { Overinvestment }_{i, t} \\
& +\lambda_{13} \text { Dividend }_{i, t} \times \text { Overinvestment }_{i, t}
\end{aligned}
$$

Eqn (2) indicates the impact of leverage on firm performance at specific levels of dividend and overinvestment. $\lambda_{8}$ captures the effect of debt in companies which do not pay dividends and do not have overinvestment.

\subsection{The marginal effect of dividend}

$$
\frac{\partial \text { Performance }_{i, t}}{\partial \text { Dividend }_{i, t}}=\lambda_{7}+\lambda_{10} \text { Debt }_{i, t}+\lambda_{12} \text { Overinvestment }_{i, t}+\lambda_{13} \text { Debt }_{i, t} \times \text { Overinvestment }_{i, t}
$$


JABES

28,1

Eqn (3) shows the effect of dividend on firm performance at certain levels of debt and overinvestment. $\lambda_{7}$ captures the impact of dividend in companies which do not use leverage and do not have overinvestment.

\subsection{The marginal effect of overinvestment}

\section{2}

$$
\frac{\partial \text { Performance }_{i, t}}{\partial \text { Overinvestment }_{i, t}}=\lambda_{9}+\lambda_{11} \text { Debt }_{i, t}+\lambda_{12} \text { Dividend }_{i, t}+\lambda_{13} \text { Dividend }_{i, t} \times \text { Debt }_{i, t}
$$

Eqn (4) indicates the impact of overinvestment at specified levels of overinvestment. $\lambda_{9}$ captures the effect of overinvestment in companies which do not use leverage and do not pay dividends.

The study applies two alternative measures for overinvestment, HP filter and investment demand function. Firstly, HP filter is a technique employed to remove the cyclical component from the raw time series. The smoothness of the trend line depends on the multiplier $\lambda$. The higher multiplier means the time series becomes less sensitive to short-term fluctuations (Hodrick and Prescott, 1997). This method has been used in previous studies to estimate potential GDP and identify whether a country should boost or restrain economic growth (Altăr et al., 2010; Fedderke and Mengisteab, 2017). Recently, it has also been applied to calculate the credit gap, the difference between real credit and trend credit (HP filter) (Kocsis and Sallay, 2018; Drehmann and Yetman, 2018). Therefore, the research takes advantage of HP filter to draw the trend line of firm investment. Then, it subtracts the real value of investment from the HP filter investment. The positive difference means that the real points lie above the trend line. The research denotes these points as the sign of overinvestment because the current investment level is higher than the long-term investment. However, Hamilton (2018) supposes that HP filter has two disadvantages including: (1) It creates spurious dynamics and (2) the dynamics at the end of the sample are different from those in the middle. Therefore, the method is considered as an alternative for the sub-equation model to check the robustness and is not added to the main regression results. Secondly, overinvestment is calculated by subtracting the real value to the fitted value of the expected investment drawn from investment demand function (Richardson, 2006; He and Kyaw, 2018). To mitigate the problem of variable omissions, other control variables including size, growth, liquidity, and tangibility are included in the regression model (Chen et al., 2017; Altaf and Shah, 2017; Fosu, 2013). Table 1 introduces the summary statistics of both dependent and independent variables. Out of the three alternative proxies of firm performance, EBT over

\begin{tabular}{lccccc}
\hline Variable & Obs. & Mean & Std. Dev. & Min & Max \\
\hline EBIT/total assets & 5,852 & 0.06303 & 0.05617 & -0.05633 & 0.25661 \\
EBT/total assets & 5,852 & 0.07616 & 0.06644 & -0.05505 & 0.30079 \\
EAT/total assets & 5,852 & 0.09405 & 0.06422 & -0.02993 & 0.31353 \\
Company size & 5,852 & 26.6709 & 1.28151 & 23.8265 & 29.8310 \\
Risk & 5,853 & 0.07834 & 0.06975 & 0.00407 & 0.37840 \\
Liquidity & 5,852 & 1.67759 & 1.17572 & 0.25585 & 6.92789 \\
Tangibility & 5,816 & 0.25386 & 0.19531 & 0.00478 & 0.79431 \\
Dividend & 3,996 & 0.53488 & 0.44375 & 0.05574 & 3.22060 \\
Debt & 6,099 & 0.50751 & 0.22459 & 0.01251 & 0.94379 \\
Overinvestment IDF & 4,366 & 0.35044 & 0.47716 & 0.00000 & 1.00000 \\
Source(s): Calculated by the authors & & & & \\
\hline
\end{tabular}

Table 1.

Summary statistics 
total assets has the highest fluctuation from $-5.5 \%$ to $3 \%$. Overinvestment measured by investment demand function has the mean value of 0.35 , ranging from 0 (without overinvestment) to 1 (with overinvestment). Debt is the variable with the highest number of observations $(6,099)$, and dividend has the smallest $(3,966)$. In short, the summary statistics do not show any abnormalities in the data sample.

The research suggests that the main regression will follow the dynamic model. The dynamic approach adds the lag of the dependent variable into the model as an independent variable. The model clarifies the adjustment of the dependent variable to its previous value (Karanasos, 2001; Karanasos and Kim, 2006). Economically, it is obvious that previous performance will affect current performance. Companies who performed effectively in the past will have favourable conditions to maintain their efficiency in the future (Duru et al., 2016; Shao, 2019). When this model is applied, pooled ordinary least square (POLS), fixed effects (FE) and random effect (RE) for panel data may not be suitable because it will make variable coefficients biased. In this case, the most appropriate one is system generalized methods of moments (SGMM) (Roodman, 2009; Bun and Windmeijer, 2010). This technique provides the endogenous lagged dependent variable with strong instruments. It uses the difference values of lagged dependent variables as instruments for the level equation and the lagged dependent variables as instruments for the difference equation. Noticeably, SGMM is only valid in case the overidentification restrictions (Sargan and Hansen tests) are satisfied, autocorrelation with the higher order than 1 does not exist in the difference equation (Arellano-Bond tests) and the number of groups is higher than the number of instruments.

\section{Results}

Table 2 indicates the main regression with firm performance as the dependent variable. Overinvestment is defined as the positive error term obtained from investment demand function. The research uses three alternative proxies for firm performance including earnings before interests and taxes over total assets (model 1), earnings before taxes over total assets (model 2) and earnings after taxes over total assets (model 3).

The main variables include debt, dividend and overinvestment. In Model 1, the marginal effects of these variables are shown as follows.

\subsection{The marginal effect of debt}

$$
\begin{aligned}
\frac{\partial \text { Performance }_{i, t}}{\partial \text { Debt }_{i, t}}= & -0.0528+0.000762 \times \text { Dividend }_{i, t}+0.0358 \times \text { Overinvestment }_{i, t} \\
& -0.00679 \times \text { Dividend }_{i, t} \times \text { Overinvestment }_{i, t}
\end{aligned}
$$

Firstly, the marginal effect of debt shows that if companies do not pay out dividends and do not have overinvestment, financial leverage will have a negative effect on firm performance. The negative sign supports the stance that when companies have more debt in the capital structure, they will face higher risks of financial distress and bankruptcy. Therefore, they will have to incur higher interest payments, which results in a lower profitability (Anh and Thao, 2019). Secondly, companies pay out dividends to shareholders but do not experience the problem of overinvestment. In this case, the marginal effect of debt will depend on a certain level of dividend payments. The positive sign of the interaction between leverage and dividend implies the substitution effect between these two policies, which can be explained by two mechanisms. First, when a company increases debt in the capital structure, dividend payment signals that the company is operating effectively. Thus, its credit worthiness is not 
JABES

28,1

54

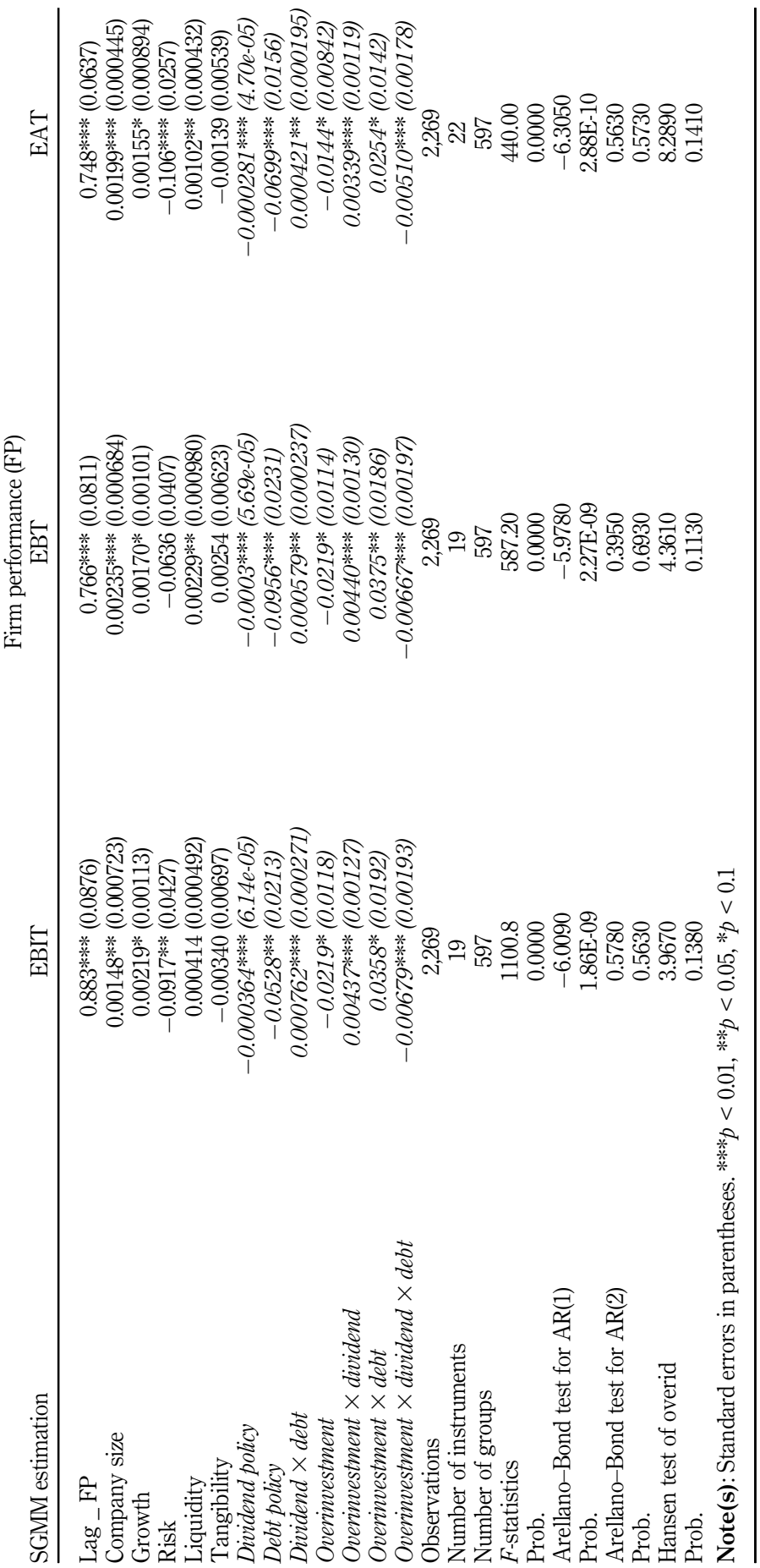

Table 2.

Main regression 
seriously devaluated, and it does not suffer from a high financing cost, which can lead to better profitability. Second, the obligations of interest and dividend payments towards debtholders and shareholders also encourage managers to manage companies more efficiently. As a result, the use of dividend policy together with debt policy can help improve firm performance. Thirdly, companies have a problem of overinvestment but do not pay out dividends. The marginal effect of debt relies on overinvestment. Overinvestment can moderate the negative effect of debt on firm performance. Overinvestment means that companies tend to invest in unprofitable projects and firm management is not effective. In the situation, firms are at higher risk of financial distress and bankruptcy, which forces companies to enhance their efficiency and limit their debt obligations. Finally, companies both pay out dividends and have the problem of overinvestment. In this circumstance, the marginal effect of debt is dependent on dividend and overinvestment. Although the presence of dividend or overinvestment in a company separately can mitigate the negative effect of debt, the combination of these two elements together with debt policy is more likely to lessen the positive moderation of either overinvestment or dividend. In real life, if a company with debt in the capital structure aims to improve its performance, it has to limit the problem of overinvestment in case it pays out dividends to shareholders, and it should not have dividend payments if it is experiencing overinvestment.

\subsection{The marginal effect of dividend}

$$
\begin{aligned}
\frac{\partial \text { Performance }_{i, t}}{\partial \text { Dividend }_{i, t}}= & -0.000364+0.000762 \times \text { Debt }_{i, t}+0.00437 \times \text { Overinvestment }_{i, t} \\
& -0.00679 \times \text { Debt }_{i, t} \times \text { Overinvestment }_{i, t}
\end{aligned}
$$

Firstly, the marginal effect of dividend indicates that if companies do not use debt and do not have overinvestment, dividend policy is negatively related to firm performance. The negative sign implies that when companies pay more dividends to shareholders, they have fewer funds to finance their investment in profitable projects to increase profitability (Rajverma et al., 2019; Chosiah et al., 2019). Secondly, companies use debt in the capital structure but do not have overinvestment. The marginal effect of dividend will be adjusted by a specific level of leverage. The positive interaction coefficient of debt and dividend suggests the substitution effect between these two policies. Dividend payments will reduce a firm's financing firm. If it can restore to other sources like debt, it can have enough funds to finance investment projects to heighten profitability in the future. Hence, the use of debt together with the pay-out of dividends can constrain the negative effect of a single dividend policy. Thirdly, companies have overinvestment but do not use debt in the capital structure. The marginal effect of dividend depends on overinvestment. The results show that overinvestment can positively regulate the negative relationship between dividend policy and firm performance. When a company wants to make more investment without borrowing, it has to retain more profits and limit dividend payments. The problem of overinvestment requires the company to pay out less and reduce the negative effect of dividend. Finally, companies both use debt in the capital structure and have overinvestment. In this case, the marginal effect of dividend relies on both debt and overinvestment. Similarly, the existence of debt or overinvestment in a company can lessen the negative effect of dividend; however, these combined factors tend to reduce the positive moderation of either debt or overinvestment towards the dividendperformance relationship. In reality, if a company who pays out dividends to shareholders aims to enhance its performance, it has to prevent overinvestment in case it uses debt in the capital structure, and it should not increase borrowings under the problem of overinvestment. 
JABES

28,1

56

\subsection{The marginal effect of overinvestment}

$$
\frac{\text { PPerformance }_{i, t}}{\text { Ovverinvestment }_{i, t}}=-0.0219+0.00437 \times \text { Dividend }_{i, t}+0.0358 \times \text { Debt }_{i, t}
$$

$$
-0.00679 \times \text { Dividend }_{i, t} \times \text { Debt }_{i, t}
$$

Firstly, the marginal effect of overinvestment shows that if companies do not use debt and do not pay dividends, overinvestment negatively affects firm performance. The negative effect of overinvestment can be explained by agency problems. Agency theory suggests that interest conflicts between managers and shareholders may be harmful to companies. Managers desire to increase financial sources under their management by increasing investment. They even invest in unprofitable projects, leading to the problem of overinvestment. To mitigate agency problems, companies have to incur certain business costs to monitor and to compensate managers. The finding is similar to some empirical studies on overinvestment among Chinese companies (Yu et al., 2020; Setianto and Pratiwi, 2019). Secondly, companies use debt in the capital structure but do not pay out dividends. The marginal effect of overinvestment will be determined by a specified level of debt. The positive interaction between overinvestment and debt implies that financial leverage can reduce the negative effect of overinvestment. According to free cash flow hypothesis, the use of debt requires companies to satisfy their obligations towards creditors, which reduces discretionary funds to make inefficiency investment. Thus, financial leverage can hamper the detrimental influence of overinvestment on firm performance. Thirdly, companies have dividend payments but do not use debt in the capital structure. The marginal effect of overinvestment is dependent of dividend. The positive interaction between overinvestment and dividend means that dividend payments can decrease the negative effect of overinvestment. Similar to debt, the pay-out of dividends implies that companies attempt to satisfy shareholders, which reduces financing funds for discretionary use. Therefore, dividend policy can relieve the negative effect of overinvestment on firm performance. The research finding supports the idea that financial leverage and dividend payments may shrink excessive free cash flow and mitigate the problem of overinvestment (Chi and Chau, 2019). Finally, companies use debt in the capital structure and pay out dividends to shareholders. In this circumstance, the marginal effect of overinvestment depends on both debt and dividend. Astonishingly, the combined policies in the decision-making process diminish the constraining impact of a single policy. Although the use of debt or the payment of dividends can help reduce excessive free cash flow, their combination lowers financing funds to the lowest level. Therefore, if companies need to finance profitable projects in the future, they will be lacking funds and will have to ignore beneficial investment. In this case, companies are experiencing underinvestment which is harmful to firm performance. In practice, if a company that has the problem of overinvestment wants to improve its performance, it should only use either debt or dividend policy to cut off the free cash flow because the combined policies may push it into underinvestment, which reduces the effectiveness previously brought in by each policy.

In addition to main variables, the research also takes into account a few control variables including size, sales growth, liquidity, tangibility and the one-period lag of firm performance (the dynamic approach). Firm size has a significantly negative effect on firm performance. This clarifies that when companies increase their sizes, they may have difficulties in controlling their resources and tend to operate less effectively (Vu et al., 2019; Corvino et al., 2019). Sales growth is positively related to firm performance. When companies operate effectively, they are more likely to increase their sales (Mohan and Chandramohan, 2018; Jia, 2020). Business risk is negatively significant to firm performance. When companies conduct more risky investment projects, their profitability may variate over time, raising their risk of 
bankruptcy (Sutrisno, 2019; Indrabudiman and Farida, 2018). Liquidity is significant in some models and not significant in the others. However, the positive sign indicates that when companies have high liquidity, they can have more financing funds to invest in profitable projects so as to improve firm efficiency (Chen et al., 2019; Batten and Vo, 2019). Tangibility does not have a significant effect on firm performance. It clarifies that fixed assets do not determine how effectively companies operate (Tripathy and Shaik, 2020; Alam et al., 2020).

The study uses two ways to check the robustness of the estimated results: (1) It applies alternative proxies for the dependent variable (EBIT/total assets, EBT/total assets and EAT/ total assets); (2) it employs two methods to measure overinvestment (investment demand function and HP filter) [2]. All coefficients are consistent in signs and the significance level. Moreover, necessary tests for the dynamic approach are all satisfied in six models. First, the Hansen test for the overidentification proves that instruments are valid and strong enough to deal with the endogenous problem caused by the lag of the dependent variable. Second, the $\mathrm{AR}(1)$ and $\mathrm{AR}(2)$ test indicates that the dependent variable has the first-order autocorrelation but not the second-order autocorrelation. Thirdly, the number of groups is much higher than the number of instruments.

\section{Conclusion}

It is obvious that the three financial policies including debt, dividend and investment policy are interdependent of one another; they are collaboratively applied to determine how efficiently a company operates. Based on agency theory and free cash flow hypothesis, the research clarifies overinvestment caused by the conflicts of interests between shareholders and managers as well as the moderating effects of debt and dividend policy on overinvestment. Using the data of non-financial listed companies in Ho Chi Minh City and Hanoi Stock Exchange in the period of 2008-2018, the research concludes that overinvestment is negatively related to profitability and that debt and dividends can moderate such an adverse impact by reducing excessive free cash flow. Notably, when these two policies are combined, they degenerate the overinvestment-profitability nexus due to the substitution between debt policy and dividend policy. The study uses two alternative proxies for overinvestment built on HP filter and investment demand function.

Using the data of non-financial Vietnamese listed companies in the period of 2008-2018, the research concludes that profitability is negatively associated with overinvestment. Remarkably, the use of debt or the pay-out of dividends tends to lessen the negative effect of overinvestment by mitigating excessive free cash flow within corporate enterprises. However, because debt and dividend policy are substituted to each other, the combination of these two policies adversely regulates the overinvestment-profitability relationship. Two alternative proxies of overinvestment are estimated by HP Filter (the points above the investment linear line) and investment demand function (the positive residual taken from the sub-equation). The replacement of proxies for both independent (overinvestment) and dependent (firm performance) variables indicates consistent estimated coefficients and significance level, demonstrating the regression robustness.

Based on major findings from the estimated results, the research proposes three policy recommendations. First, a company can exploit debt or dividend policy to limit excessive free cash flow, constraining the problem of overinvestment. Second, a company should enhance its corporate governance so as to deal with agency problems. Third, the government should make the financial sector more transparent and effective in order to improve monitoring functions of various parties in the capital market.

\section{Notes}

1. See Table A1 for the description of all variables in the main model and overinvestment estimation. 
JABES

28,1

58

2. The estimated results for HP filter are presented in Table A3 as an alternative measure of overinvestment to check the robustness of the regression model.

\section{References}

Al-Najjar, B. and Kilincarslan, E. (2019), "What do we know about the dividend puzzle?-A literature survey", International Journal of Managerial Finance, Vol. 15, pp. 205-235.

Alam, A., Uddin, M., Yazdifar, H., Shafique, S. and Lartey, T. (2020), "R\&D investment, firm performance and moderating role of system and safeguard: evidence from emerging markets", Journal of Business Research, Vol. 106, pp. 94-105.

Ali, M.J., Balachandran, B., Michael, M. and Theobald, M. (2019), "Do corporate general counsels mitigate agency problems? Evidence from dividend policy decisions", Evidence from Dividend Policy Decisions, (accessed 3 April 2019).

Alli, K.L., Khan, A.Q. and Ramirez, G.G. (1993), "Determinants of corporate dividend policy: a factorial analysis", Financial Review, Vol. 28, pp. 523-547.

Alsharairi, M., Smith, D.D., Glambosky, M. and Gleason, K. (2018), "Firm investment efficiency and auditor perception of dividend initiation”, Quarterly Journal of Finance and Accounting, Vol. 56.

Altaf, N. and Shah, F. (2017), "Working capital management, firm performance and financial constraints: empirical evidence from India", Asia-Pacific Journal of Business Administration, Vol. 9, pp. 206-219.

Altăr, M., Necula, C. and Bobeică, G. (2010), "Estimating potential GDP for the Romanian economy. An eclectic approach", Romanian Journal of Economic Forecasting, Vol. 3, pp. 5-25.

Anh, N.T. and Thao, T.T.P. (2019), "The impact of capital structure on firm performance of Vietnamese non-financial listed companies based on agency cost theory", VNU Journal of Science: Economics and Business, Vol. 35.

Badavar Nahandi, Y. and Taghizadeh Khanqah, V. (2018), "The impact of political connections on overinvestment and firm performance", Journal of Accounting and Auditing Review, Vol. 25, pp. 181-198.

Baker, H.K. and Powell, G.E. (2000), "Determinants of corporate dividend policy: a survey of NYSE firms", Financial Practice \& Education, Vol. 10, pp. 29-40.

Batten, J. and Vo, X.V. (2019), "Liquidity and firm value in an emerging market", The Singapore Economic Review, Vol. 64, pp. 365-376.

Bhuiyan, M.B.U. and Hooks, J. (2019), "Cash holding and over-investment behavior in firms with problem directors", International Review of Economics and Finance, Vol. 61, pp. 35-51.

Biddle, G.C., Hilary, G. and Verdi, R.S. (2009), "How does financial reporting quality relate to investment efficiency?", Journal of Accounting and Economics, Vol. 48, pp. 112-131.

Brealey, R.A., Myers, S.C. and Allen, F. (2008), "Brealey, myers, and allen on real options", Journal of Applied Corporate Finance, Vol. 20, pp. 58-71.

Bun, M.J. and Windmeijer, F. (2010), "The weak instrument problem of the system GMM estimator in dynamic panel data models", The Econometrics Journal, Vol. 13, pp. 95-126.

Chen, Y.C., Hung, M. and Wang, Y. (2017), "The effect of mandatory CSR disclosure on firm profitability and social externalities: evidence from China", Journal of Accounting and Economics.

Chen, J., Hong, H., Huang, M. and Kubik, J.D. (2019), Replication Data for: Does Fund Size Erode Mutual Fund Performance? the Role of Liquidity and Organization.

Chi, L.H.D. and Chau, N.T.M. (2019), "Overinvestment and free cash flow: empirical evidence from Vietnamese enterprises", Asian Journal of Economics and Banking (AJEB).

Cho, E.J., Lee, J.H. and Park, J.S. (2019), "The impact of leverage and overinvestment on project financing: evidence from South Korea", Asia-Pacific Journal of Accounting and Economics, pp. 1-23. 
Chosiah, C., Purwanto, B. and Ermawati, W.J. (2019), "Dividend policy, investment opportunity set, free cash flow, and company performance: Indonesian's agricultural sector”, Jurnal Keuangan dan Perbankan, Vol. 23, pp. 403-417.

Corvino, A., Caputo, F., Pironti, M., Doni, F. and Martini, S.B. (2019), "The moderating effect of firm size on relational capital and firm performance", Journal of Intellectual Capital.

Debt and dividend policy on overinvestment

Ding, S., Knight, J. and Zhang, X. (2019), "Does China overinvest? Evidence from a panel of Chinese firms", The European Journal of Finance, Vol. 25, pp. 489-507.

Drehmann, M. and Yetman, J. (2018), Why You Should Use the Hodrick-Prescott Filter-At Least to Generate Credit Gaps.

Duru, A., Iyengar, R.J. and Zampelli, E.M. (2016), “The dynamic relationship between CEO duality and firm performance: the moderating role of board independence", Journal of Business Research, Vol. 69, pp. 4269-4277.

Easterbrook, F.H. (1984), "Two agency-cost explanations of dividends", The American Economic Review, Vol. 74, pp. 650-659.

Farooq, S., Ahmed, S. and Saleem, K. (2014), Impact of Overinvestment \& Underinvestment on Corporate Performance: Evidence from Singapore Stock Market.

Fedderke, J.W. and Mengisteab, D.K. (2017), "Estimating South Africa's output gap and potential growth rate", South African Journal of Economics, Vol. 85, pp. 161-177.

Fosu, S. (2013), "Capital structure, product market competition and firm performance: evidence from South Africa", The Quarterly Review of Economics and Finance, Vol. 53, pp. 140-151.

$\mathrm{Fu}, \mathrm{F}$. (2010), "Overinvestment and the operating performance of SEO firms", Financial Management, Vol. 39, pp. 249-272.

Gordon, M.J. (1959), "Dividends, earnings, and stock prices”, The Review of Economics and Statistics, pp. 99-105.

Gordon, M.J. (1963), "Optimal investment and financing policy”, The Journal of Finance, Vol. 18, pp. 264-272.

Grazzi, M., Jacoby, N. and Treibich, T. (2016), "Dynamics of investment and firm performance: comparative evidence from manufacturing industries", Empirical Economics, Vol. 51, pp. 125-179.

Grossman, S.J. and Hart, O.D. (1982), Corporate Financial Structure and Managerial Incentives. The Economics of Information and Uncertainty, University of Chicago Press.

Gu, L. (2013), Three Essays on Financial Economics, University of Illinois at Urbana-Champaign.

Guariglia, A. and Yang, J. (2016), "A balancing act: managing financial constraints and agency costs to minimize investment inefficiency in the Chinese market", Journal of Corporate Finance, Vol. 36, pp. 111-130.

Hao, X., Wang, Y. and Peng, S. (2018), "The effect of debt structure on overinvestment: based on Chinese real estate listed companies", Journal of Asia Entrepreneurship and Sustainability, Vol. 14, pp. 196-223.

He, W. and Kyaw, N.A. (2018), "Ownership structure and investment decisions of Chinese SOEs", Research in International Business and Finance, Vol. 43, pp. 48-57.

Hodrick, R.J. and Prescott, E.C. (1997), "Postwar US business cycles: an empirical investigation", Journal of Money, Credit, and Banking, pp. 1-16.

Indrabudiman, A. and Farida, I. (2018), "Relationship of business risk, financial and performance: evidence from Indonesia”, International Journal of Pure and Applied Mathematics, Vol. 119, pp. 16523-16530.

Jensen, M.C. (1986), “Agency costs of free cash flow, corporate finance, and takeovers”, The American Economic Review, Vol. 76, pp. 323-329.

Jensen, M.C. and Meckling, W.H. (1976), "Theory of the firm: managerial behavior, agency costs and ownership structure", Journal of Financial Economics, Vol. 3, pp. 305-360. 
JABES

28,1

Jia, X. (2020), "Corporate social responsibility activities and firm performance: the moderating role of Strategic emphasis and industry competition”, Corporate Social Responsibility and Environmental Management, Vol. 27, pp. 65-73.

Jiang, J., Liu, B. and Yang, J. (2019), “The impact of debt restructuring on firm investment: evidence from China”, Economic Modelling.

Kannadhasan, M. and Aramvalarthan, S. (2011), Relationships Among Business Strategy, Environmental Uncertainty and Performance of Firms Operating in Transport Equipment Industry in India.

Karanasos, M. (2001), "Prediction in ARMA models with GARCH in mean effects", Journal of Time Series Analysis, Vol. 22, pp. 555-576.

Karanasos, M. and Kim, J. (2006), “A re-examination of the asymmetric power ARCH model”, Journal of Empirical Finance, Vol. 13, pp. 113-128.

Kim, H.S. (2018), "Investment decisions, debt renegotiation friction, and agency conflicts", International Review of Finance.

Kocsis, L. and Sallay, M. (2018), "Credit-to-GDP gap calculation using multivariate HP filter”, $M N B$ Occasional Papers.

Kumar, S. and Ranjani, K. (2018), "Dividend behaviour of Indian-listed manufacturing and service sector firms", Global Business Review, Vol. 20, pp. 179-193.

Lang, L.H. and Litzenberger, R.H. (1989), "Dividend announcements: cash flow signalling vs free cash flow hypothesis?”, Journal of Financial Economics, Vol. 24, pp. 181-191.

Lei, Q. and Chen, H. (2019), "Corporate governance boundary, debt constraint, and investment efficiency", Emerging Markets Finance and Trade, Vol. 55, pp. 1091-1108.

Li, C., Zhou, P. and Li, Y. (2019), "Managerial overconfidence, overinvestment, and R\&D spillover", Managerial and Decision Economics.

Litzenberger, R.H. and Ramaswamy, K. (1979), "The effect of personal taxes and dividends on capital asset prices: theory and empirical evidence", Journal of Financial Economics, Vol. 7, pp. 163-195.

Liu, N. and Bredin, D. (2010), Institutional Investors, Over-investment and Corporate Performance, University College Dublin.

López-De-Foronda, Ó., López-De-Silanes, F., López-Iturriaga, F.J. and Santamaría-Mariscal, M. (2019), "Overinvestment, leverage and financial system liquidity: a challenging approach", $B R Q$ Business Research Quarterly, Vol. 22, pp. 96-104.

Miller, M.H. and Modigliani, F. (1961), "Dividend policy, growth, and the valuation of shares", The Journal of Business, Vol. 34, pp. 411-433.

Modigliani, F. and Miller, M.H. (1958), "The cost of capital, corporation finance and the theory of investment”, The American Economic Review, Vol. 48, pp. 261-297.

Modigliani, F. and Miller, M.H. (1963), "Corporate income taxes and the cost of capital: a correction", The American Economic Review, Vol. 53, pp. 433-443.

Mohan, A. and Chandramohan, S. (2018), "Impact of corporate governance on firm performance: empirical evidence from India", IMPACT: International Journal of Research in Humanities, Arts and Literature (IMPACT: IJRHAL) ISSN (P), pp. 2347-4564.

Myers, S.C. and Majluf, N.S. (1984), "Corporate financing and investment decisions when firms have information that investors do not have", Journal of Financial Economics, Vol. 13, pp. 187-221.

Rajverma, A.K., Misra, A.K., Mohapatra, S. and Chandra, A. (2019), "Impact of ownership structure and dividend on firm performance and firm risk", Managerial Finance.

Richardson, S. (2006), "Over-investment of free cash flow", Review of Accounting Studies, Vol. 11, pp. 159-189.

Roodman, D. (2009), "How to do xtabond2: an introduction to difference and system GMM in Stata", STATA Journal, Vol. 9, pp. 86-136. 
Rozeff, M.S. (1982), "Growth, beta and agency costs as determinants of dividend payout ratios", Journal of Financial Research, Vol. 5, pp. 249-259.

Setianto, R.H. and Pratiwi, A. (2019), "Working capital management in Indonesia: an analysis on overinvestment and underinvestment firms", Gadjah Mada International Journal of Business, Vol. 21, p. 1.

Debt and dividend policy on overinvestment

Shao, L. (2019), "Dynamic study of corporate governance structure and firm performance in China", Chinese Management Studies.

Shi, M. (2019), "Overinvestment and corporate governance in energy listed companies: evidence from China”, Finance Research Letters.

Shi, J. and Gao, Y. (2018), "Ownership concentration, free cash flow and over-investment", 2018 5th International Conference on Industrial Economics System and Industrial Security Engineering (IEIS), IEEE, pp. 1-5.

Shima, K. (2010), "Lumpy capital adjustment and technical efficiency”, Economics Bulletin, Vol. 30, pp. 2817-2824

Sutrisno, S. (2019), "Capital structure, business risk and corporate performance (case study on construction and real estate sector)", Perisai: Islamic Banking and Finance Journal, Vol. 3, p. 83.

Titman, S., Wei, K.J. and Xie, F. (2004), "Capital investments and stock returns”, Journal of Financial and Quantitative Analysis, Vol. 39, pp. 677-700.

Tripathy, S. and Shaik, A. (2020), "Leverage and firm performance: empirical evidence from Indian food processing industry", Management Science Letters, Vol. 10, pp. 1233-1240.

Vu, T.H., Nguyen, V.D., Ho, M.T. and Vuong, Q.H. (2019), "Determinants of Vietnamese listed firm performance: competition, wage, CEO, firm size, age, and international trade", Journal of Risk and Financial Management, Vol. 12, p. 62.

Wei, X., Wang, C. and Guo, Y. (2019), "Does quasi-mandatory dividend rule restrain overinvestment?", International Review of Economics and Finance, Vol. 63, pp. 4-23.

Yang, W. (2005), Corporate Investment and Value Creation, Indiana University Bloomington.

Yeo, H.J. (2018), "Role of free cash flows in making investment and dividend decisions: the case of the shipping industry", The Asian Journal of Shipping and Logistics, Vol. 34, pp. 113-118.

Yu, X., Yao, Y., Zheng, H. and Zhang, L. (2020), "The role of political connection on overinvestment of Chinese energy firms", Energy Economics, Vol. 85, p. 104516.

\section{Further reading}

Deangelo, H., Deangelo, L. and STULZ, R.M. (2006), "Dividend policy and the earned/contributed capital mix: a test of the life-cycle theory", Journal of Financial Economics, Vol. 81, pp. 227-254.

\section{Corresponding author}

Cong Thanh Nguyen can be contacted at: nc.thanh93@hutech.edu.vn 
JABES

28,1

62

Table A1.

Variable measurements

\section{Appendix}

$$
\begin{aligned}
\text { Performance }_{i, t}= & \lambda_{0}+\lambda_{1} \text { Performance }_{i, t-1}+\lambda_{2} \text { Size }_{i, t}+\lambda_{3} \text { Growth }_{i, t}+\lambda_{4} \text { Risk }_{i, t} \\
& +\lambda_{5} \text { Liquidity }_{i, t}+\lambda_{6} \text { Tangibility }_{i, t}+\lambda_{7} \text { Dividend }_{i, t}+\lambda_{8} \text { Debt }_{i, t} \\
& +\lambda_{9} \text { Overinvestment }_{i, t}+\lambda_{10} \text { Dividend }_{i, t} \times \text { Debt }_{i, t} \\
& +\lambda_{11} \text { Debt }_{i, t} \times \text { Overinvestment }_{i, t}+\lambda_{12} \text { Dividend }_{i, t} \times \text { Overinvestment }_{i, t} \\
& +\lambda_{13} \text { Dividend }_{i, t} \times \text { Debt }_{i, t} \times \text { Overinvestment }_{i, t}+\mu_{i, t}
\end{aligned}
$$

\begin{tabular}{|c|c|c|}
\hline Variables & Denote & Definition \\
\hline \multicolumn{3}{|c|}{ Dependent variables } \\
\hline Firm & EBIT/TA & EBIT (earnings before interest and tax) divided by total assets \\
\hline performance & EBT/TA & EBT (earnings before tax) divided by total assets \\
\hline & $\mathrm{EAT} / \mathrm{TA}$ & EAT (earnings after tax) divided by total assets \\
\hline \multicolumn{3}{|c|}{ Explanatory variables } \\
\hline Risk & Risk $_{i, t}$ & Standard deviation of ROA \\
\hline Company growth & Growth $_{i, t}$ & Growth rates of total sales \\
\hline Dividend & Dividend $_{i, t}$ & Cash dividend pay-outs over earnings after taxes \\
\hline Debt & Debt $_{i, t}$ & Total liabilities/total assets \\
\hline Liquidity & Liquidity $_{i, t}$ & Quick ratio (current assets - inventories)/current liabilities \\
\hline Tangibility & Tangibility $_{i, t}$ & Tangible fixed assets/total assets \\
\hline Overinvestment & Overinvestment $_{i, t}$ & $\begin{array}{l}\text { Investment residual measured by overinvestment estimation with } \\
\nu_{i, t}>0 \text { and Hodrick-Prescott filter }\end{array}$ \\
\hline Firm size & Size $_{i, t}$ & Natural logarithm of total assets \\
\hline
\end{tabular}

$$
\begin{aligned}
\text { Invesment }_{i, t}^{N E W}= & \lambda_{1} \text { DebitRatio }_{i, t}+\lambda_{2} \text { Risk }_{i, t}+\lambda_{3} \text { CompanySize }_{i, t}+\lambda_{4} \text { SaleGrowth }_{i, t} \\
& +\lambda_{5} \text { AssetTurnover }_{i, t}+\lambda_{6} \text { GrowthOption }_{i, t}+\lambda_{7} \text { CashFlow }_{i, t}+V_{i, t}
\end{aligned}
$$

\begin{tabular}{lll}
\hline Variables & Denote & Definition \\
\hline
\end{tabular}

Dependent variables

New investment Investment ${ }_{i, t}^{N E W}$

Explanatory variables

Cash flow

Market

performance

Asset turnover

CashFlow $_{i, t}$ GrowthOption $_{i, t}$

AssetTurnover ${ }_{i, t}$

Firm growth $\quad$ SaleGrowth $_{i, t}$

Firm size

Business risk

CompanySize $_{i, t}$

Risk $_{i, t}$
Total investment including long-term and short-term investment divided by total asset

The cash available in a company after subtracting capital expenditures Growth option is Tobin's Q ratio calculated as the market value of a company divided by the firm's assets

The ability to generate fixed assets through sales measured by total fixed assets divided by total sales

The growth rate of firm sales over year

Natural logarithm of total assets

Standard deviation of EBITDA (earnings before interest, taxes, depreciation and amortization) over total asset ratio in three consecutive years

Total liabilities over total assets
Table A2.

Overinvestment estimation
Leverage

DebtRatio $_{i, t}$

Note(s): All the above variables are calculated by using financial data from Thomson Reuters Eikon Financial Analysis 


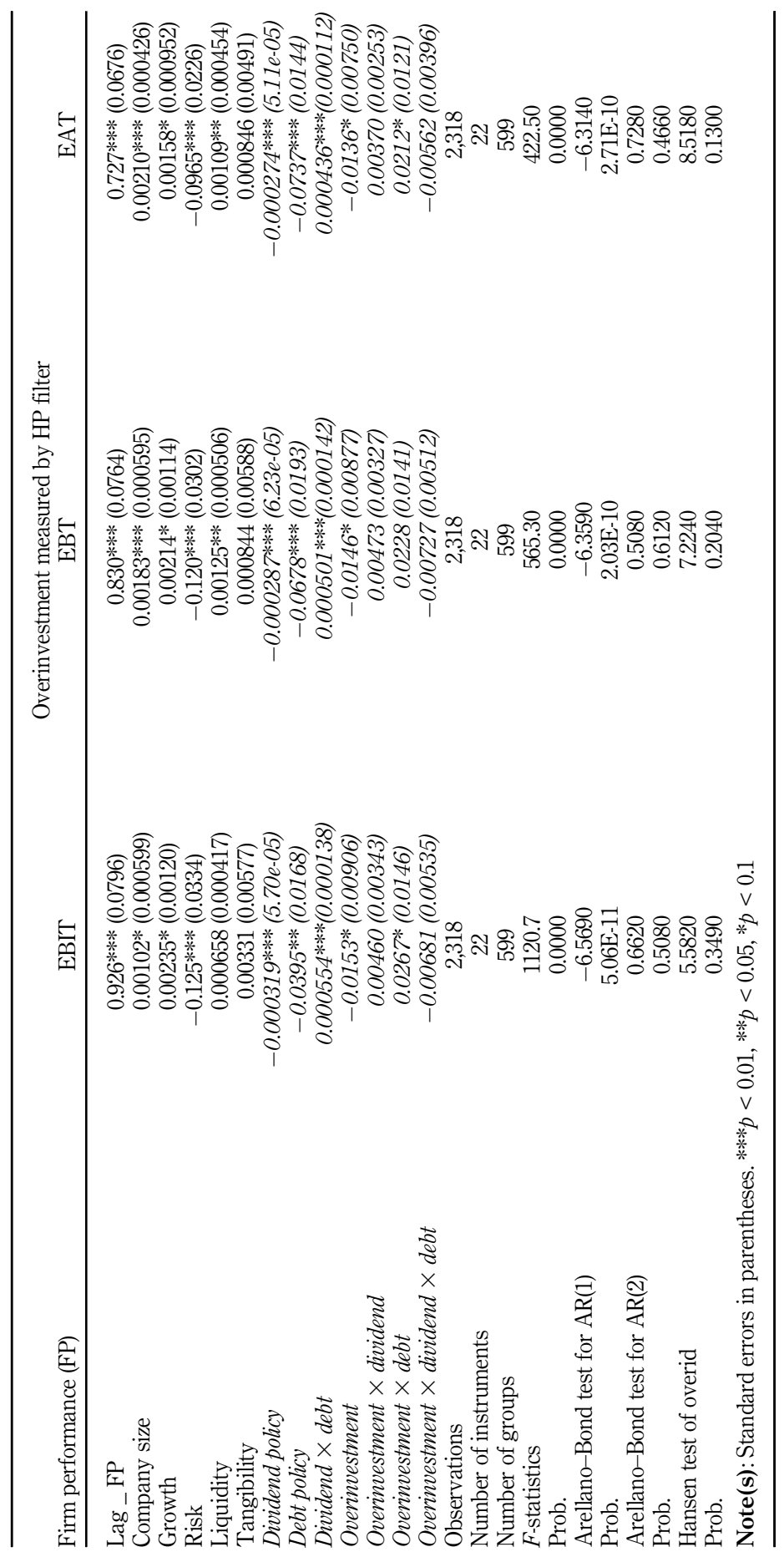

Debt and dividend policy on overinvestment

63

Table A3.

Estimated results using HP-filter technique to measure overinvestment 